BMC

\title{
Microbiology
}

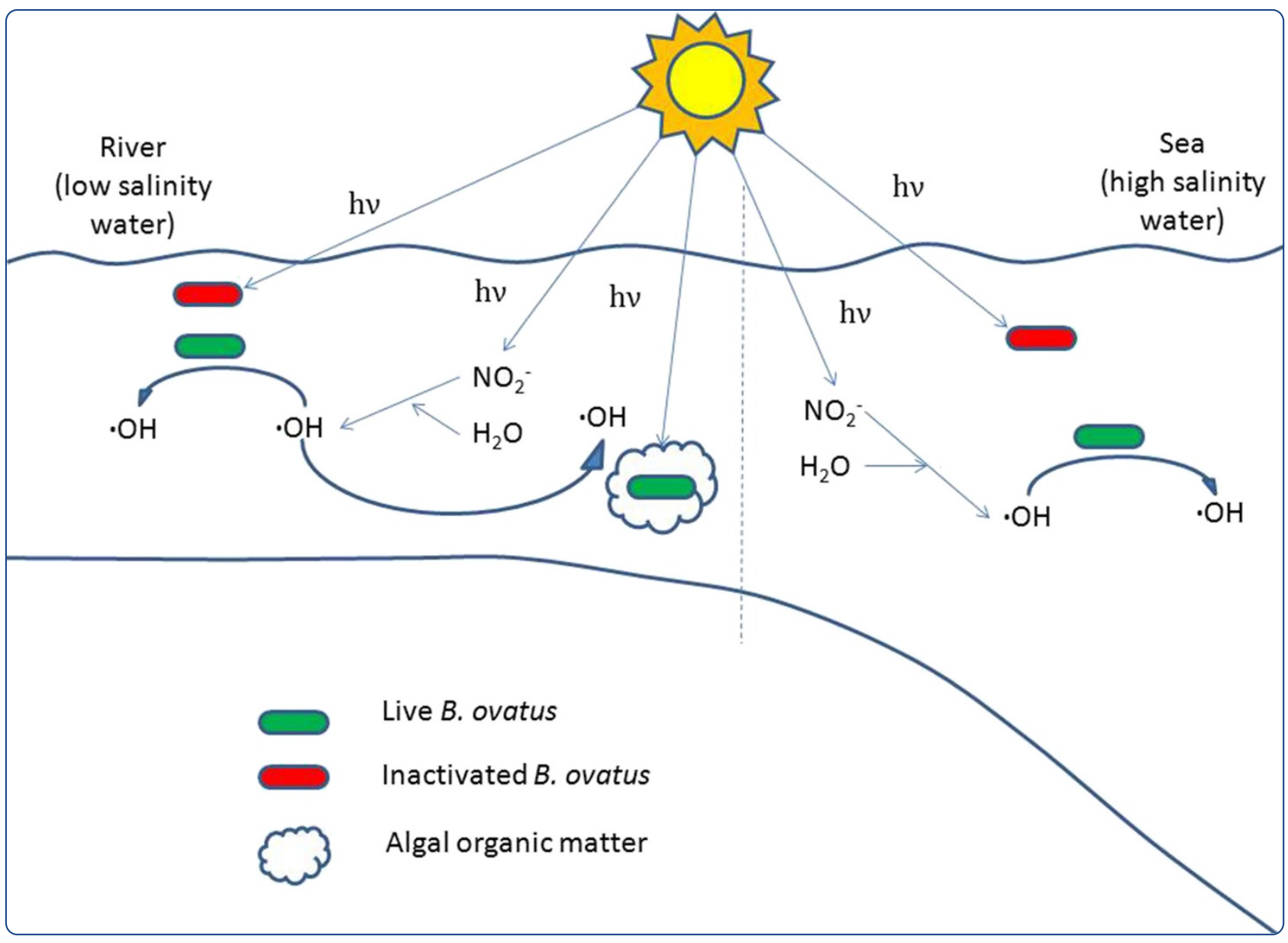

\section{Persistence of Bacteroides ovatus under simulated sunlight irradiation}

Dong et al. 


\title{
Persistence of Bacteroides ovatus under simulated sunlight irradiation
}

Shengkun Dong ${ }^{1}$, Pei-Ying Hong ${ }^{2^{*}}$ and Thanh $\mathrm{H}_{\text {Nguyen }}{ }^{1 *}$

\begin{abstract}
Background: Bacteroides ovatus, a member of the genus Bacteroides, is considered for use in molecular-based methods as a general fecal indicator. However, knowledge on its fate and persistence after a fecal contamination event remains limited. In this study, the persistence of $B$. ovatus was evaluated under simulated sunlight exposure and in conditions similar to freshwater and seawater. By combining propidium monoazide (PMA) treatment and quantitative polymerase chain reaction (qPCR) detection, the decay rates of $B$. ovatus were determined in the presence and absence of exogenous photosensitizers and in salinity up to 39.5 parts per thousand at $27^{\circ} \mathrm{C}$.

Results: UVB was found to be important for B. ovatus decay, averaging a $4 \log _{10}$ of decay over $6 \mathrm{~h}$ of exposure without the presence of extracellular photosensitizers. The addition of $\mathrm{NaNO}_{2}$, an exogenous sensitizer producing hydroxyl radicals, did not significantly change the decay rate of $B$. ovatus in both low and high salinity water, while the exogenous sensitizer algae organic matter (AOM) slowed down the decay of B. ovatus in low salinity water. At seawater salinity, the decay rate of $B$. ovatus was slower than that in low salinity water, except when both $\mathrm{NaNO}_{2}$ and AOM were present.

Conclusion: The results of laboratory experiments suggest that if $B$. ovatus is released into either freshwater or seawater environment in the evening, $50 \%$ of it may be intact by the next morning; if it is released at noon, only $50 \%$ may be intact after a mere 5 min of full spectrum irradiation on a clear day. This study provides a mechanistic understanding to some of the important environmental relevant factors that influenced the inactivation kinetics of B. ovatus in the presence of sunlight irradiation, and would facilitate the use of B. ovatus to indicate the occurrence of fecal contamination.
\end{abstract}

Keywords: Bacteroides ovatus, Sunlight irradiation, Fate and persistence, Seawater, Freshwater, PMA-qPCR

\section{Background}

Earlier studies have reported that the occurrence of gastrointestinal illness in both fresh and coastal waters has been found to correlate statistically with the presence of fecal indicator bacteria (FIB) such as coliforms and enterococci $[1,2]$. As such, the culture-dependent method to enumerate conventional FIBs is commonly used for detecting fecal contamination. However, this method has always been challenged for various reasons. First, most conventional FIBs can proliferate under natural conditions after being released into the environment, and

\footnotetext{
* Correspondence: peiying.hong@kaust.edu.sa; thn@illinois.edu

${ }^{2}$ Water Desalination and Reuse Center, Environmental Science and Engineering Program, King Abdullah University of Science and Technology (KAUST), 4700 King Abdullah Boulevard, Thuwal 23955-6900, Saudi Arabia ${ }^{1}$ Department of Civil and Environmental Engineering, University of Illinois at Urbana-Champaign, 205 N. Mathews, 3230 Newmark Lab, Urbana, IL 61801, USA
}

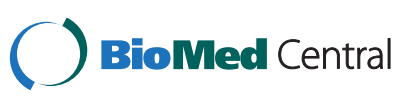

(c) 2014 Dong et al.; licensee BioMed Central Ltd. This is an Open Access article distributed under the terms of the Creative Commons Attribution License (http://creativecommons.org/licenses/by/2.0), which permits unrestricted use, distribution, and reproduction in any medium, provided the original work is properly credited. The Creative Commons Public Domain Dedication waiver (http://creativecommons.org/publicdomain/zero/1.0/) applies to the data made available in this article unless otherwise stated. the detection of these FIBs may overestimate the original contamination level. Second, monitoring the cause of waterborne illness based on conventional FIBs underestimates the actual number of FIBs as it excludes the viable but non-culturable cells [3]. Third, most conventional FIBs exist in feces of a number of warm-blooded animals, which would not allow identification of the host origin [4]. Lastly, FIBs require incubation time of 24-48 h, posing a possibility for people to be exposed to contaminated water before regulatory announcements can be made [5].

Molecular-based approaches like quantitative polymerase chain reaction (qPCR) assays targeting genetic markers for 16S rRNA genes of fecal indicators can be used to overcome the disadvantages of using culture-dependent methods to evaluate fecal contamination. A combination of qPCR and propidium monoazide (PMA) pretreatment has been developed for the Bacteroides spp. to distinguish 
between cells with intact membrane and cells with compromised membrane [6]. The Bacteroides spp. have been proposed to replace conventional FIBs [7] as a general indicator for fecal contamination because they are commonly isolated from feces [8] or numerically abundant in feces [9].

Recently, US EPA validated the use of the qPCR approach to quantify the Bacteroidales genetic marker for fecal contamination detection [8]. Among the genus Bacteroides, Bacteroides ovatus is considered for use as a general fecal contamination indicator [10]. However, the different Bacteroidales species have been demonstrated to have different durations of persistence, which is likely due to environmental factors and the stability of DNA markers [9]. This different persistence would make it challenging to track the bacterial indicator. Exposure of the Bacteroidales (species) cells to sunlight irradiation may be one of the important environmental processes that significantly influence their persistence in surface water [11-13]. DNA marker from the Bacteroidales could persist for days or weeks in naturally sunlit seawater and low salinity water environments [14]. Longer persistence of these genetic markers was observed at lower temperatures and higher salinities $[15,16]$. Natural sunlight was found to have negligible effect on the persistence of these genetic markers [17]. However, variation of natural sunlight irradiation in time and location hinders the application of data obtained with natural sunlight from one location to the other. Accurate correlation between persistence of the $\mathrm{Bac}$ teroidales cells and sunlight irradiation may, therefore, facilitate the use of these bacterial populations as fecal indicators.

Three fundamental photoinactivation mechanisms have been identified for microorganisms: direct inactivation, indirect exogenous inactivation, and indirect endogenous inactivation. Direct inactivation refers to the direct damage of the cellular components such as the genome and proteins by shorter wavelengths of sunlight $[18,19]$. This mechanism has been suggested as the dominant mechanism in bacterial photoinactivation in some cases [19]. Indirect endogenous inactivation involves the light absorption by sensitizers that belong to the cell. These sensitizers eventually either pass electrons to other cellular components or create reactive oxygen species that inactivate the cell [19-22]. However, it is difficult to experimentally distinguish direct inactivation and indirect endogenous inactivation $[23,24]$. Indirect exogenous inactivation usually starts with photo-excitation of the exogenous light sensitizers, such as natural organic matter and nitrate, which react with dissolved oxygen and produce reactive oxygen species such as $\cdot \mathrm{OH}$ that can oxidize and damage cellular components [20]. Nevertheless, the contribution of each mechanism to the inactivation of each specific bacterium species is still unclear [25]. Study on inactivation mechanisms of $B$. ovatus is particularly lacking.

The objective of this study was therefore to evaluate the decay of $B$. ovatus under conditions similar to both freshwater and coastal seawater, in the presence of controlled simulated sunlight and extracellular algal natural organic matter (AOM) from Skeletonema costatum. This algal species was chosen due to its wide distribution globally [26]. The PMA-qPCR approach was used to differentiate and enumerate cells with and without intact membrane. The mechanisms controlling the decay of $B$. ovatus were determined based on the results of experiments, which were designed to answer a number of questions on the effects of sunlight UV irradiation and the roles that exogenous photosensitizers $\left(\mathrm{NO}_{2}{ }^{-}\right.$and $\mathrm{AOM}$ ), and water salinity would have on the persistence of fecal indicator $B$. ovatus in the water environment (see Additional file 1: Table S1 for a summary of research questions, experimental design, and findings).

\section{Methods}

\section{B. ovatus cultivation}

A lyophilized Bacteroides ovatus strain ATCC 8483 received from American Type Culture Collection was first suspended in inoculating fluid (Biolog Inc. 72401), followed by inoculation in anaerobic medium [27] with a modified glucose content of $0.5 \%(\mathrm{w} / \mathrm{v})$. After the cell suspension reached an optical density at $600 \mathrm{~nm}\left(\mathrm{OD}_{600}\right)$ of $1,0.5 \mathrm{ml}$ of the suspension was collected and subsequently inoculated into a serum bottle with $60 \mathrm{ml}$ of anaerobic medium. B. ovatus cells were harvested after $14.5 \mathrm{~h}$ of incubation at $37^{\circ} \mathrm{C}$ by centrifugation at $15,557 \mathrm{~g}$ for $16 \mathrm{~min}$ at $20^{\circ} \mathrm{C}$. The pellets were washed three times with $10 \mathrm{mM}$ sterilized phosphate buffer solution at $\mathrm{pH} 8.2$ by sequential centrifugation at $15,557 \mathrm{~g}$ before irradiation experiments.

\section{Extracellular AOM preparation}

Bulk microalgae solution of the species $S$. costatum LB 2308 propagated in Erdschreiber's medium was purchased from The Culture Collection of Algae at the University of Texas at Austin (UTEX). The bulk solution was subject to centrifugation at $2740 \mathrm{~g}$ for $10 \mathrm{~min}$, and the supernatant containing organic cell exudates was collected. The supernatant was filtered through a cellulose acetate membrane of $1.2 \mu \mathrm{m}$ pore size (EPS ${ }^{\circ}$, Inc.) to remove algae cells and debris. The filtered supernatant was subjected to dialysis using $3.5 \mathrm{k}$ Dalton MWCO membrane (Thermo Scientific SnakeSkin, 88245) against deionized water. The dialysis concentrate, which is referred to as the extracellular AOM, was harvested when the solution conductivity was below $10 \mu \mathrm{S} / \mathrm{cm}$. The extracellular AOM after dialysis had total organic carbon (TOC) of $1.94 \mathrm{mg}$ C/L, specific UV 
absorbance at $254 \mathrm{~nm}$ SUVA of 1.03, $\mathrm{pH}$ of 6.18 , and salinity $<1$ parts per thousand at $27^{\circ} \mathrm{C}$.

\section{Experimental setup}

Eighty $\mathrm{ml}$ glass beakers (Pyrex) were used as microcosms, which were wrapped with black tape (3 M) to prevent the reflected and deteriorated simulated sunlight screened by the beaker from reaching the liquid inside the microcosm. Mixing was facilitated by a Variomag electronic stirrer set at $130 \mathrm{rpm}$. Seawater temperatures recorded near King Abdullah University of Science and Technology (KAUST) were $20^{\circ} \mathrm{C}$ in February 2013 and $36^{\circ} \mathrm{C}$ in May 2013. Therefore, experiments in this temperature range were conducted. Temperature of the reactors was regulated by a water bath set at $27^{\circ} \mathrm{C}$. A reactor covered with a piece of aluminum foil was used as the dark control.

Solar exposure was conducted in an Atlas Suntest ${ }^{\circ}$ XLS + photosimulator (Chicago, IL) equipped with a xenon arc lamp. A $280 \mathrm{~nm}$ cutoff filter (Newport, MA) was placed on top of reactors to prevent liquid loss through evaporation. A $320 \mathrm{~nm}$ cutoff filter (Newport, MA) was used to determine the significance of UVB for B. ovatus inactivation. An ILT950 spectroradiometer (International light technologies, MA) was used to measure the irradiance from 280 to $700 \mathrm{~nm}$ inside the solar simulator. The xenon arc lamp was set at an irradiance of $400 \mathrm{Wm}^{-2}$ with a UV special glass filter, which delivers $3248 \mu \mathrm{W} / \mathrm{cm}^{2}$ of UV irradiance received by the reactors. In comparison, the UV irradiance on the University of Illinois campus in Urbana during a clear day at $12 \mathrm{pm}$ on April $22^{\text {nd }}$ was $3899 \mu \mathrm{W} / \mathrm{cm}^{2}$, and on October $21^{\text {st }}$ a total UV irradiance of $2618 \mu \mathrm{W} / \mathrm{cm}^{2}$ was measured at around $2 \mathrm{pm}$ on the KAUST campus during a clear day in Jeddah, Saudi Arabia. To convert the irradiance $\left(\mu \mathrm{W} / \mathrm{cm}^{2}\right)$ to fluence $\left(\mathrm{J} / \mathrm{cm}^{2}\right)$, cumulative irradiance over $280-700 \mathrm{~nm}$ wavelength for a specified duration of time was calculated.

A final cell concentration of $10^{9}-10^{10}$ cells $/ \mathrm{ml}$ was used for all solar exposure experiments. For experiments with low salinity and without AOM, $10 \mathrm{mM}$ sterilized phosphate buffer solution (Fisher Scientific Inc.) was prepared to resuspend the washed $B$. ovatus cell pellet to $60 \mathrm{ml}$. Samples were taken intermittently after the initiation of the exposure to the simulated sunlight. $1.2 \mathrm{ml}$ of aliquot was drawn out of each microcosm and stored at $-20^{\circ} \mathrm{C}$ for a day before DNA extraction using the Ultraclean Soil DNA Isolation Kit (Mo-Bio, CA) following the manufacturer's instructions. Two batches of samples were collected from a given reactor, one was treated with PMA to determine intact cell count and the other was not. Both batches were subsequently enumerated with qPCR assay. For reactors with AOM, natural organic matter stock solution was added to the beaker, and $500 \mathrm{mM}$ sterilized phosphate buffer (Fisher Scientific Inc.) was used to adjust the $\mathrm{pH}$ to 8.2. Ionic strength was then compensated with sodium chloride to $10 \mathrm{mM}$. For selected experiments, $10 \mathrm{mg} / \mathrm{L}$ of $\mathrm{NaNO}_{2}$ was used as synthetic sensitizer of - $\mathrm{OH}$. Preliminary experiments on Escherichia coli to optimize the majority of the workflow were done in triplicates. Experiments done on B. ovatus were conducted five times as a result of the power analysis $(1-\beta=80 \%)$.

To mimic the high salinity condition that $B$. ovatus may experience upon being released into the sea, solar exposure experiments were also conducted in artificial seawater, containing $32 \mathrm{~g} / \mathrm{L}$ of sodium chloride, $0.8 \mathrm{~g} / \mathrm{L}$ of potassium chloride, $1.3 \mathrm{~g} / \mathrm{L}$ of calcium chloride, and $6.1 \mathrm{~g} / \mathrm{L}$ of magnesium chloride. This ionic concentration was selected to match salinity of Red Sea water at 39.5 parts per thousand collected on the KAUST campus [28]. Experiments conducted with this artificial seawater were referred to as high salinity, while experiments conducted with solutions of $10 \mathrm{mM}$ ionic strength were referred to as low salinity.

\section{Propidium monoazide (PMA) treatment}

PMA (Biotium Inc., CA) was used to count cells with intact membrane. This chemical binds to double stranded DNA in both the extracellular environment and in cells with compromised membrane, preventing subsequent qPCR amplification as previously described in other studies [6,17]. $2 \mathrm{mM}$ of PMA stock solution was prepared using $20 \%$ DMSO as the solvent and stored in the dark at $-20^{\circ} \mathrm{C}$ until used. For each PMA treatment, $63 \mu \mathrm{l}$ of the stock solution was added into the $1.2 \mathrm{ml}$ sample to achieve $100 \mu \mathrm{M}$ of the final PMA concentration. The samples containing PMA were incubated for $5 \mathrm{~min}$ on a rotary shaker in the dark, followed by exposure to two $500 \mathrm{~W}$ halogen lamps for $6 \mathrm{~min}$ at a distance of $20 \mathrm{~cm}$ to photoactivate the dye. During the exposure, the samples were placed on top of the aluminum foil with a tray of ice beneath them to prevent samples from overheating.

\section{Quantitative PCR (qPCR)}

Amplification and detection of the targeted 16S rRNA gene of $B$. ovatus were used to enumerate both intact and/or compromised cells. 384-well clear optical reaction plates (Applied Biosystems ${ }^{\circ}, \mathrm{CA}$ ) were used in an ABI PRISM 7500 HT real time quantitative PCR machine (Applied Biosystems ${ }^{\circ}$, CA). A MicroAmp optical adhesive film (Applied Biosystems ${ }^{\circ}, \mathrm{CA}$ ) was used to cover each 384-well clear optical reaction plate to prevent evaporation and contamination. Each $15 \mu \mathrm{l}$ qPCR reaction mixture contained $2 \mu \mathrm{l}$ of DNA template and $13 \mu \mathrm{l}$ of qPCR mastermix. The mastermix consisted of a mixture of Power SYBR Green (Applied Biosystems ${ }^{\circ}, \mathrm{CA}$ ), $0.2 \mu \mathrm{M}$ Bac32F and Bac303R primers (IDT, IA), and molecular biology grade water (Thermo Scientific, MA). Triplicate analysis was done for each sample, and a standard curve was generated with serial dilution of Promega $\mathrm{pGEM}^{\ominus}-\mathrm{T}$ 
Easy Vector (Madison, WI) harboring the entire 16S rRNA gene from $B$. ovatus. The thermal cycling parameters include an initial $2 \mathrm{~min}$ at $50^{\circ} \mathrm{C}$, followed by $10 \mathrm{~min}$ at $95^{\circ} \mathrm{C}$, and 40 cycles of $15 \mathrm{~s}$ at $95^{\circ} \mathrm{C}$ and $1 \mathrm{~min}$ at $60^{\circ} \mathrm{C}$. A dissociation cycle of $15 \mathrm{~s}$ at $95^{\circ} \mathrm{C}$, followed by $15 \mathrm{~s}$ at $60^{\circ} \mathrm{C}$, ramping up to $95^{\circ} \mathrm{C}$ for $15 \mathrm{~s}$ was done to assess for nonspecific amplification. Two samples that contained all the qPCR reagents except for the DNA samples were prepared as negative controls to check for PCR contamination. The detection limit for the Bac32 F and Bac303R primers is 29 copies per reaction, with amplification efficiency for the set of primers ranging from $90-94 \%$.

\section{Decay rate calculations}

B. ovatus cells with intact membrane will be referred as "intact cells" and cells with compromised membrane will be referred as "compromised cells" below. Pseudo-first decay model was used to fit the data and $k_{o b s}$, the pseudofirst decay rate constant, was obtained by linear regression fitting. Light screening correction was done on $k_{o b s}$ to account for the light absorption and scattering in the solution [29]. Besides the inactivation rate constant, the halflife of $B$. ovatus decay was also calculated. Paired sample $t$-test was used to determine if the treatment group was significantly different from the dark control group. Oneway ANOVA test was done to determine if $k_{o b s}$ or half-life among more than three treatment groups were significantly different from each other. Power $1-\beta=80 \%$ was used for all statistical tests.

\section{Results}

\section{Influence of UV irradiation on B. ovatus decay}

For the full spectrum irradiation experiment at $27^{\circ} \mathrm{C} \mathrm{com}-$ prising UVB, UVA, and visible light exposure, $4 \log _{10}$ of decay was observed over $6 \mathrm{~h}$ of experiment, with a pseudo-first decay rate constant $\left(k_{o b s}\right)$ significantly different from zero $(\mathrm{p}<0.05, \alpha=0.05$, Table 1, Figure 1$)$. The total $B$. ovatus cells, including both intact and compromised, decreased $25 \%$ over $6 \mathrm{~h}$ of exposure to full solar spectrum. When UVB was blocked and B. ovatus cells were exposed to $6 \mathrm{~h}$ of simulated sunlight containing only UVA and visible light, $1.5 \log _{10}$ of decay was observed. The presence of UVB clearly led to faster B. ovatus decay, reflecting in an additional $2.5 \log _{10}$ of decay over $6 \mathrm{~h}$ of exposure. As a result, to reveal a more prominent decay trend in subsequent experiments, full spectrum irradiation containing UVB, UVA, and visible light was used. In low salinity water irradiated by full spectrum simulated sunlight, the half-life calculated based on the pseudo-first decay model for intact cells was $0.08 \mathrm{~h}$, or $4.8 \mathrm{~min}$. This half-life is significantly shorter than $9 \mathrm{~h}$, which was determined for cells kept in the dark. For the dark control, no significant growth or decay was observed (Figure 1).
Table 1 Decay rate constants observed for $B$. ovatus

\begin{tabular}{|c|c|c|}
\hline Condition & $\begin{array}{l}k_{\text {obs }} \text { in } \mathrm{hr}^{-1} \text { for low } \\
\text { salinity water } \\
\text { (half-life in } \mathrm{h} \text { ) }\end{array}$ & $\begin{array}{l}k_{o b s} \text { in } \mathrm{hr}^{-1} \text { for high } \\
\text { salinity water } \\
\text { (half-life in h) }\end{array}$ \\
\hline \multirow{2}{*}{$\begin{array}{l}\text { Phosphate buffer irradiated } \\
\text { by UVA and visible light }\end{array}$} & $4.1 \pm 2.0$ & \multirow[t]{2}{*}{ Not available } \\
\hline & $(0.21 \pm 0.12)$ & \\
\hline \multirow{2}{*}{$\begin{array}{l}\text { Phosphate buffer irradiated } \\
\text { by full spectrum }\end{array}$} & $9.1 \pm 1.0$ & $3.3 \pm 0.4$ \\
\hline & $(0.08 \pm 0.009)$ & $(0.21 \pm 0.02)$ \\
\hline \multirow[t]{2}{*}{ Phosphate buffer dark control } & $0.08 \pm 0.04$ & $-0.01 \pm 0.04$ \\
\hline & $(9.17 \pm 3.28)$ & $(4 \% \text { increase })^{*}$ \\
\hline \multirow{2}{*}{$\begin{array}{l}\text { Phosphate buffer and } \mathrm{NaNO}_{2} \\
\text { irradiated by full spectrum }\end{array}$} & $6.7 \pm 1.7$ & $4.2 \pm 0.3$ \\
\hline & $(0.11 \pm 0.02)$ & $(0.17 \pm 0.01)$ \\
\hline \multirow{2}{*}{$\begin{array}{l}\text { Phosphate buffer and } \mathrm{NaNO}_{2} \\
\text { dark control }\end{array}$} & $0.06 \pm 0.04$ & $0.02 \pm 0.01$ \\
\hline & $(12.84 \pm 7.18)$ & $(34.12 \pm 17.5)$ \\
\hline \multirow{2}{*}{$\begin{array}{l}\text { AOM solution irradiated by } \\
\text { full spectrum }\end{array}$} & $2.1 \pm 0.3$ & $4.0 \pm 1.2$ \\
\hline & $(0.34 \pm 0.05)$ & $(0.19 \pm 0.04)$ \\
\hline \multirow[t]{2}{*}{ AOM solution dark control } & $-0.02 \pm 0.04$ & $0.04 \pm 0.01$ \\
\hline & $(7 \% \text { increase })^{*}$ & $(16.18 \pm 0.19)$ \\
\hline \multirow{2}{*}{$\begin{array}{l}\mathrm{NaNO}_{2} \mathrm{AOM} \text { solution } \\
\text { irradiated by full spectrum }\end{array}$} & $4.7 \pm 1.9$ & $7.0 \pm 2.0$ \\
\hline & $(0.17 \pm 0.05)$ & $(0.1 \pm 0.03)$ \\
\hline \multirow{2}{*}{$\begin{array}{l}\mathrm{NaNO}_{2} \mathrm{AOM} \text { solution dark } \\
\text { control }\end{array}$} & $-0.05 \pm 0.08$ & $-0.03 \pm 0.02$ \\
\hline & $(36 \% \text { increase })^{*}$ & $(9 \% \text { increase })^{*}$ \\
\hline
\end{tabular}

*Half-life could not be calculated due to the increase in biomass, therefore the percentage of growth was calculated. Data were corrected for light screening. Kinetic data are also plotted in Additional file 1: Figure S1.

Influence of exogenous $\cdot \mathrm{OH}$ and algae organic matter on $B$. ovatus decay in low salinity water

The role of exogenously produced. $\mathrm{OH}$ was studied because these highly reactive radicals can non-specifically attack and oxidize cellular components [30]. Production of $0.77 \pm 0.08 \mathrm{fM} \cdot \mathrm{OH}$ in low salinity water was observed from solutions containing $0.14 \mathrm{mM} \mathrm{NaNO}$ exposed to full solar spectrum irradiation at $27^{\circ} \mathrm{C}$. The decay rate constants $\left(k_{o b s}\right)$ measured based on the intact cells were not significantly different for solutions with and without $\mathrm{NaNO}_{2}$ in the low salinity water ( $\mathrm{p}>0.1, \alpha=0.1$, Table 1 , Figure 2). These similar $k_{o b s}$ values suggested that the presence of $0.77 \pm 0.08 \mathrm{fM} \cdot \mathrm{OH}$ did not significantly impact the inactivation of $B$. ovatus in low salinity water.

Decay experiments were conducted with a solution containing $2 \mathrm{mg} \mathrm{C} / \mathrm{L}$ of extracted AOM to simulate some of the actual environmental conditions that $B$. ovatus may be exposed to after being released into the environment. This TOC value was chosen based on the seawater water quality measurement in Saudi Arabia [28]. As shown in Table 1 and Additional file 1: Figure $\mathrm{S1a}$, at $27^{\circ} \mathrm{C}$ in low salinity water, the presence of AOM slowed down the decay by more than $77 \%\left(4.71 \pm 1.86 \mathrm{~h}^{-1}\right.$ vs. $\left.9.09 \pm 0.98 \mathrm{~h}^{-1}\right)$. This observation is in agreement with lower concentrations of $\cdot \mathrm{OH}$ observed for solution containing AOM (Table 2). 


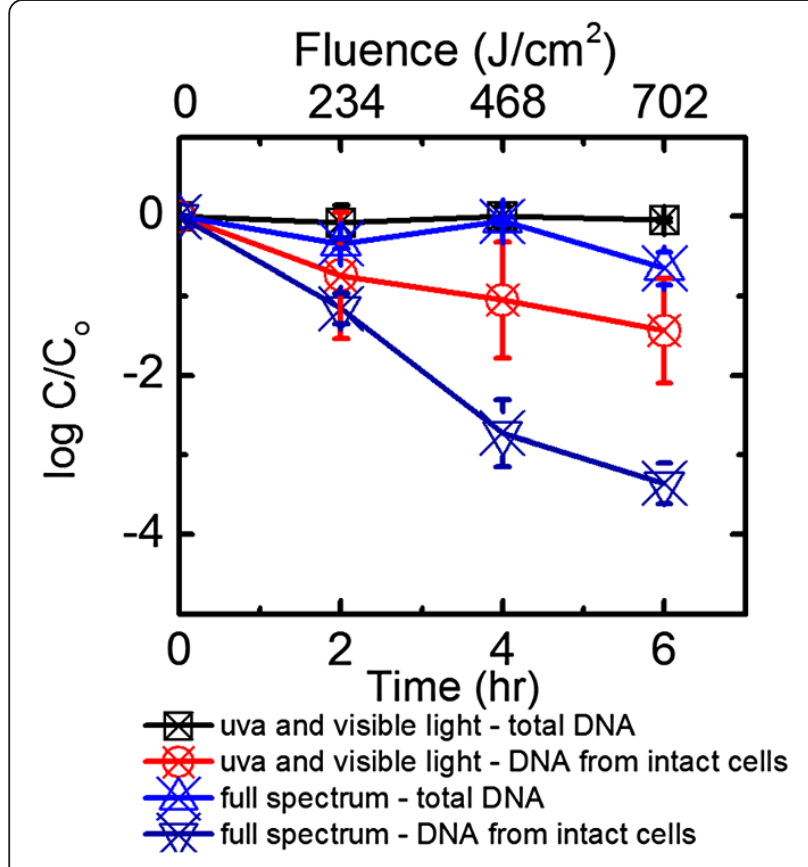

Figure 1 Comparison of the persistence of $B$. ovatus in low salinity water irradiated by full spectrum simulated sunlight and UVA with visible light. Error bars correspond to standard deviation of up to 5 replicates. Data were not corrected for light screening

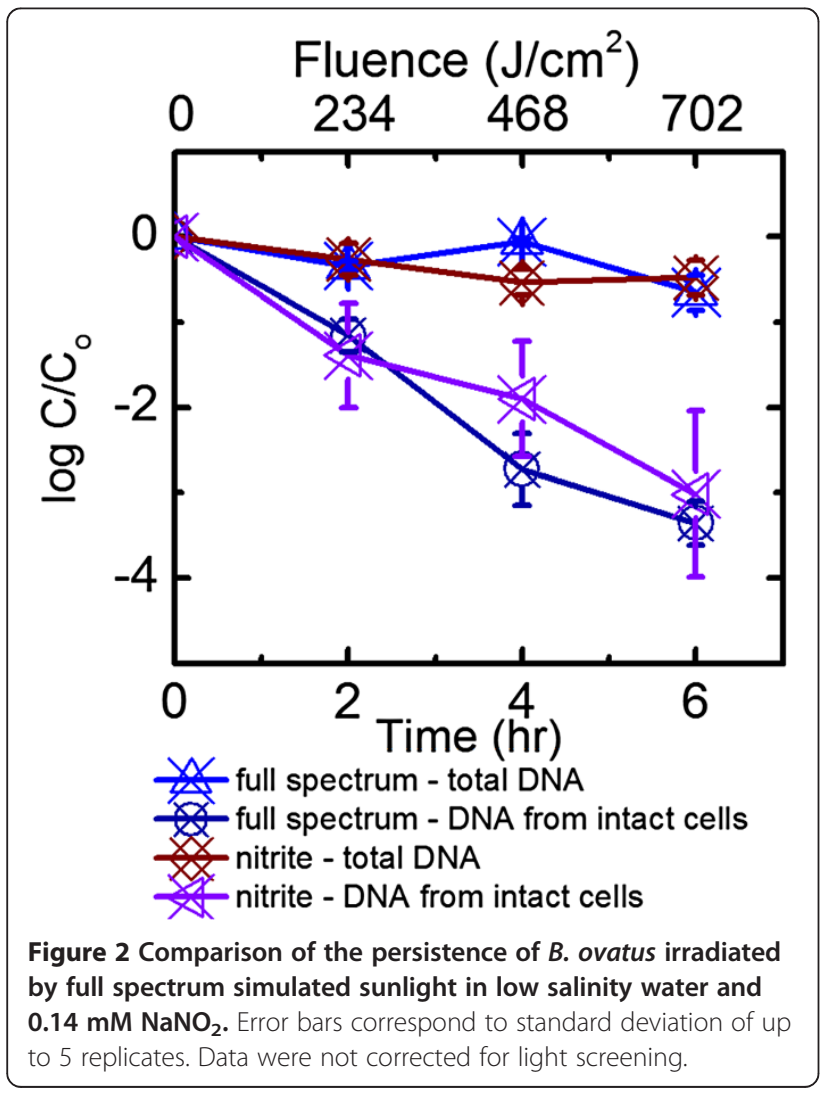

Table 2 ["OH] for different conditions

\begin{tabular}{ll}
\hline Experimental conditions & $\begin{array}{l}\text { Hydroxyl radical } \\
\text { concentration* (fM) }\end{array}$ \\
\hline Low salinity water $+\mathrm{NO}_{2}^{-}$ & $0.77 \pm 0.08$ \\
Low salinity water $+\mathrm{AOM}$ & $0.09 \pm 0.04$ \\
Low salinity water $+\mathrm{AOM}+\mathrm{NO}_{2}^{-}$ & $0.59 \pm 0.12$ \\
High salinity water $+\mathrm{NO}_{2}^{-}$ & $0.36 \pm 0.13$ \\
High salinity water $+\mathrm{AOM}$ & $0.02 \pm 0.01$ \\
High salinity water $+\mathrm{AOM}+\mathrm{NO}_{2}^{-}$ & $0.42 \pm 0.16$ \\
\hline
\end{tabular}

*Data were corrected for light screening.

The pseudo-first decay rate constants were higher in solutions with or without $\mathrm{NaNO}_{2}$ compared with those obtained in experiments containing both $\mathrm{NaNO}_{2}$ and AOM ( $<<0.15, \alpha=0.15$, Table 1$)$. These observations indicate that AOM significantly slowed down the B. ovatus inactivation.

The solution containing AOM has a half-life of $0.34 \mathrm{~h}$, the longest among the data recorded for low salinity irradiated experiments. For the solution containing $\mathrm{NaNO}_{2}$, half-life of $0.11 \mathrm{~h}$ was significantly shorter than those obtained for solutions containing AOM but not significantly different than those obtained for sensitizer-free solutions ( $p>0.05, \alpha=0.05$, Table 1). When solutions were kept in the dark, long half-life values of more than $12 \mathrm{~h}$ were observed. In addition, $7 \%$ increase in B. ovatus biomass was observed for solutions containing AOM kept in the dark.

\section{Influence of salinity on $B$. ovatus decay}

For experiments without exogenous sensitizers and experiments with only $\mathrm{NaNO}_{2}$ as the sensitizer, the decay rate constants of $B$. ovatus in high salinity solutions under full spectrum simulated sunlight were significantly smaller than that at lower salinity $(\mathrm{p}<0.05, \alpha=0.05$, Figure 3, Additional file 1: Figure S1b). Less than $1 \log _{10}$ of $B$. ovatus decay was observed over $6 \mathrm{~h}$ of exposure, with the total cell count changed insignificantly throughout the experiment. Similar to the findings with low salinity experiments, $0.14 \mathrm{mM} \mathrm{NaNO}$ in AOM-free high salinity solutions did not significantly change $B$. ovatus decay rate constants $(p>0.05, \alpha=0.05$, Table 1$)$. For AOM-containing solutions, high salinity did not lead to a significant decrease in $k_{o b s}$ values ( $>0.05, \alpha=0.05$, Table 1$)$. In both cases, $1 \log _{10}$ decay of intact $B$. ovatus was observed, with the total cell count decreased slightly over time. In solutions containing both $0.14 \mathrm{mM} \mathrm{NaNO}$ and $\mathrm{AOM}$, and only $\mathrm{AOM}$, high salinity led to faster $B$. ovatus decay compared with corresponding low salinity settings $\left(7.01 \mathrm{~h}^{-1}\right.$ vs. $4.71 \mathrm{~h}^{-1} ; 4.03 \mathrm{~h}^{-1}$ vs.2.06 $\mathrm{h}^{-1}$, Table 1$)$, despite similar $\cdot \mathrm{OH}$ concentrations $(\mathrm{p}>0.05, \alpha=0.05$, Table 2). Mixing $0.14 \mathrm{mM} \mathrm{NaNO}_{2}$ and $\mathrm{AOM}$ in a high salinity setting yielded an unexpected result, with $B$. 


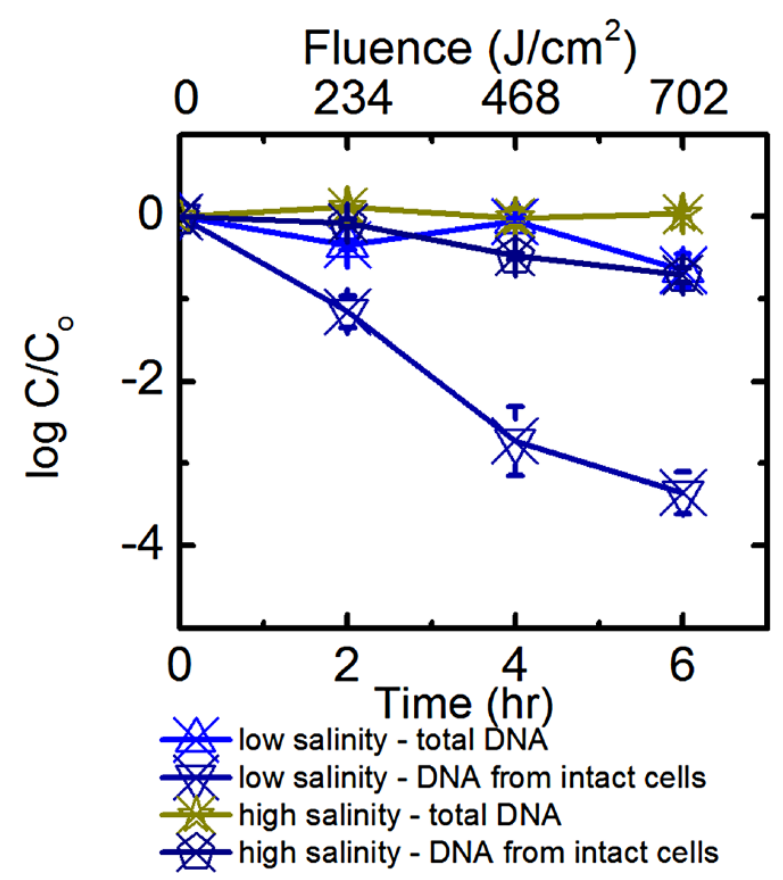

Figure 3 Comparison of the persistence of $B$. ovatus irradiated by full spectrum simulated sunlight in low salinity and high salinity water. Error bars correspond to standard deviation of up to 5 replicates. Data were not corrected for light screening. ovatus decaying faster than when either $0.14 \mathrm{mM} \mathrm{NaNO}_{2}$ or $\mathrm{AOM}$ was present alone in the high salinity environment $(\mathrm{p}<0.05, \alpha=0.05$, Table 1 , Additional file 1 : Figure S1c). However, this synergistic effect was not observed for low salinity solutions.

For high salinity solutions irradiated by full spectrum simulated sunlight, a half-life of $0.21 \mathrm{~h}$ was recorded, which was longer than that in low salinity solutions $(\mathrm{p}<0.05, \alpha=0.05$, Table 1$)$. The half-life values were statistically the same for high salinity solutions with and without $\mathrm{NaNO}_{2}(\mathrm{p}>0.05, \alpha=0.05)$. The presence of both $\mathrm{NaNO}_{2}$ and $\mathrm{AOM}$ in high salinity solutions led to the observed half-life of $0.1 \mathrm{~h}$, which was significantly shorter than when either $\mathrm{NaNO}_{2}$ or $\mathrm{AOM}$ was present alone in the high salinity environment $\left(\mathrm{p}<0.05, \alpha=0.05\right.$, Table 1). When both $\mathrm{NaNO}_{2}$ and AOM were present, high salinity half-life was also shorter than those obtained from the low salinity $(\mathrm{p}<0.05$, $\alpha=0.05$, Table 1, Figure 4). For all dark controls in high salinity experiments, the decay kinetics of total $B$. ovatus cells had a zero slope $(p>0.05, \alpha=0.05)$, indicating that salinity alone did not exert a significant impact on $B$. ovatus persistence in the dark. Irradiation experiments in high salinity water with UVB cut-off was not conducted because UVB irradiation was already identified as an important decay mechanism for B. ovatus.

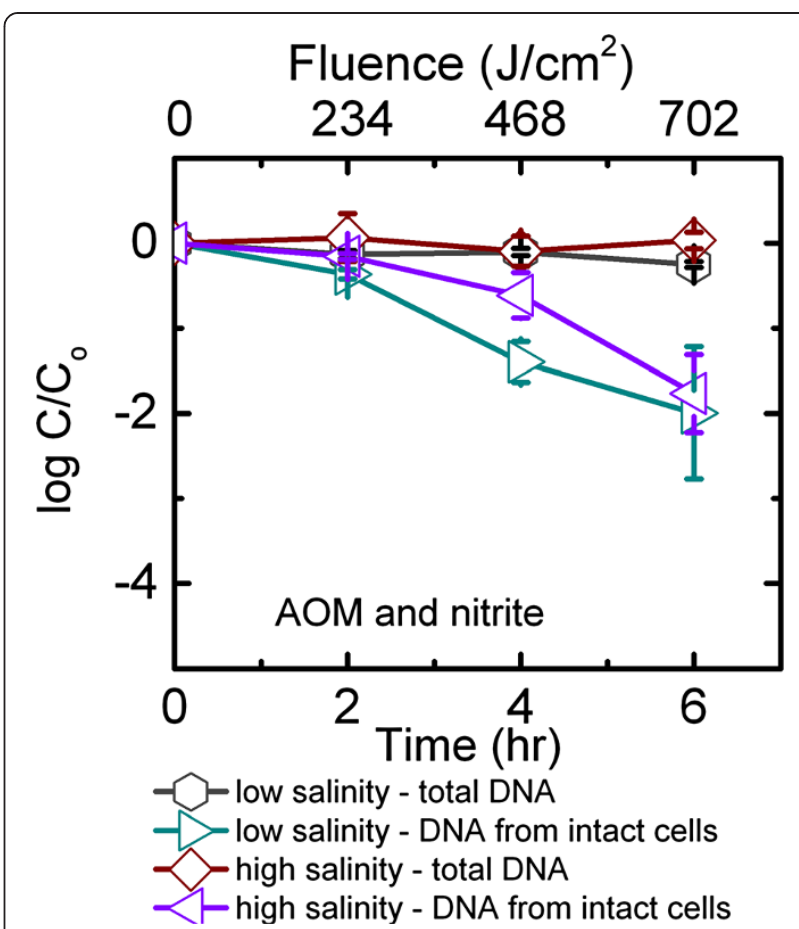

Figure 4 Persistence of $B$. ovatus irradiated by full spectrum simulated sunlight in artificial seawater containing $A O M$ and $0.14 \mathrm{mM} \mathrm{NaNO}_{2}$, and that in phosphate buffer containing AOM and $0.14 \mathrm{mM} \mathrm{NaNO}$. Error bars correspond to standard deviation of up to 5 replicates. Data were not corrected for light screening.

\section{Discussion}

\section{Mechanisms of $B$. ovatus decay}

From the dark control data for low and high salinity conditions, PMA-qPCR did not detect changes in the copy numbers of total cells (i.e., B. ovatus with both intact and compromised membrane) and intact cells, suggesting that solution conditions alone did not lead to cell decay or membrane damage. This may be explained by the fact that though $B$. ovatus are strict anaerobes, they possess superoxide dismutase, which helps to fight oxidative stress to a certain level $[31,32]$. The oxidative stress created by dissolved oxygen for dark controls happened to be within the capacity of superoxide dismutase, enabling $B$. ovatus to remain intact in the dark control. However, for irradiated samples, total cells decayed much less than intact cells, suggesting that irradiation damaged cell membranes. This is in agreement with past studies that reported damage to viral protein capsid by medium-pressure UV and endogenous inactivation of $E$. coli by UVB [33,34].

In the $6 \mathrm{~h}$ time frame of this study, more than 25\% decay of the total amount of DNA was observed as a result of UVB irradiation in the low salinity settings. This observation agrees with a previous study, where the abundance of total DNA extracted from cells decreased over time upon solar exposure in freshwater microcosms [17]. Following the method to interpret UVC inactivation of 
antibiotic resistant bacteria developed by McKinney and Pruden [35], the pyrimidine dimers for the whole genome of B. ovatus (GenBank accession NZ_DS264553DS264584) constructed from 32 scaffolds were counted with a MATLAB program and the results were presented in Table 3. The percentage of thymine dimers per B. ovatus genome size was $9.5 \%$, which was lower than that of methicillin-resistant Staphylococcus aureus, vancomycinresistant enterococci, and E. coli SMS-3-5. Compared to these bacterial species, $B$. ovatus may be more susceptible to UV irradiation than these three bacterial species because of low percentage of thymine dimers per B. ovatus genome size.

In addition, bacteria with larger genome sizes were observed to be more susceptible to UV damage, presumably because larger genomes offered more base per sites for UV damage [35]. The size of the B. ovatus constructed from 32 scaffolds was approximately $6.5 \mathrm{Mbp}$, and was larger than the genome of Pseudomonas aeruginosa 01 (i.e., $6.3 \mathrm{Mbp}$ ) that was evaluated by McKinney and Pruden [35]. P. aeruginosa 01 had the largest genome compared to methicillin-resistant $S$. aureus, vancomycinresistant enterococci, and E. coli SMS-3-5, and was determined to be most susceptible to UV damage. As such, it is likely that $B$. ovatus is equally, if not more, susceptible to UV radiation than $P$. aeruginosa 01 .

The statistically similar inactivation rate constants with and without extracellular $\cdot \mathrm{OH}$ produced by $\mathrm{NaNO}_{2}$, both in low or high salinity settings, suggest that exogenous inactivation was much less significant than endogenous inactivation mechanism for $B$. ovatus. Specifically, the presence of exogenous $\cdot \mathrm{OH}$ produced by $0.14 \mathrm{mM}$ of $\mathrm{NaNO}_{2}$ did not promote significant $B$. ovatus decay. In surface water, nitrite is usually converted to nitrate during nitrification. Only in places with incomplete nitrification can nitrite concentrations of up to $66 \mu \mathrm{M}$ be found [36]. In seawater, the concentration of nitrite has been found to be even lower, and accounts for a concentration of $10.5 \pm 2 \mathrm{nM}$ [37]. Thus, it is likely that the persistence of B. ovatus in water bodies would not be controlled by environmentally-relevant concentration of $\cdot \mathrm{OH}$ produced by nitrite or nitrate.

The presence of AOM in the extracellular environment slowed down the decay of $B$. ovatus in the low salinity setting, suggesting that AOM may protect $B$. ovatus from sunlight irradiation. When $B$. ovatus is discharged into the low salinity water environment where $\mathrm{AOM}$ is also present on a sunny day, $50 \%$ of the total intact cells will be lost within $20 \mathrm{~min}$, persisting longer than those conditions without AOM (i.e., $5 \mathrm{~min}$ ). Our observations suggest that in pockets of freshwater directly exposed to discharge from wastewater treatment plants, it is anticipated that the AOM would be higher than $1.94 \mathrm{mg} \mathrm{C} / \mathrm{L}$ and would facilitate a longer persistence of $B$. ovatus. A possible explanation to account for a longer persistence of $B$. ovatus in low salinity water with AOM may be due to the partial coverage of the cell surface where the endogenous sensitizers are located by AOM. The solar irradiation that reaches the cell to produce endogenous reactive oxygen species could be attenuated by this layer of AOM, resulting in less endogenously produced $\cdot \mathrm{OH}$ that can inactivate the cells.

In contrast, the presence of AOM in extracellular environment did not slow down the decay of $B$. ovatus in high salinity water. This can possibly be accounted for by the partial scavenging of endogenously produced or exogenously produced $\cdot \mathrm{OH}$ in the presence of chloride ions [38]. Therefore, when B. ovatus is released into seawater with AOM, B. ovatus cells have a half-life of 11.4 min, which is essentially the same as the half-life for the high salinity water without AOM (i.e., $12.6 \mathrm{~min}$ ). A synergistic effect of $\mathrm{AOM}, \cdot \mathrm{OH}$, and high salt concentration led to a faster decay of $B$. ovatus in high salinity environment than that without $\mathrm{NaNO}_{2}(\mathrm{p}<0.05, \alpha=0.05$, Table 1). However, this synergistic effect only translates to a difference of $4.2 \mathrm{~min}$ in the half-life of $B$. ovatus, which might not be apparent when performing actual fecal monitoring efforts on-site.

Table 3 Pyrimidine dimer counts for B. ovatus and antibiotic resistant bacteria (ARBs)

\begin{tabular}{|c|c|c|c|c|c|c|c|c|c|c|c|c|c|c|c|}
\hline \multirow[b]{2}{*}{ Gene name } & \multirow[b]{2}{*}{ Genome size (bp) } & \multicolumn{5}{|c|}{ Dimers (count) } & \multicolumn{5}{|c|}{ Dimers/amplicon length (\%) } & \multicolumn{4}{|c|}{ Dimers/total dimers (\%) } \\
\hline & & $\mathrm{TT}$ & $\mathrm{CC}$ & TC & CT & Total & $\mathrm{TT}$ & $\mathrm{CC}$ & $\mathrm{TC}$ & $\mathrm{CT}$ & Total & $\mathrm{TT}$ & $\mathrm{CC}$ & $\mathrm{TC}$ & CT \\
\hline B. ovatus* & 6465369 & 612293 & 298804 & 413170 & 351734 & 1676001 & 9.5 & 4.6 & 6.4 & 5.4 & 26 & 36.5 & 17.8 & 24.7 & 21 \\
\hline \multicolumn{16}{|c|}{ Data on ARBs as a comparison from McKinney and Pruden, 2012} \\
\hline MRSA & 2872769 & 706446 & 145879 & 302081 & 766117 & 1431985 & 24.6 & 5.08 & 10.5 & 9.66 & 49.8 & 49.3 & 10.2 & 21.1 & 19.4 \\
\hline VRE & 2826716 & 638915 & 199341 & 373437 & 318366 & 1530059 & 22.6 & 7.05 & 13.2 & 11.3 & 54.1 & 41.8 & 13.0 & 24.4 & 20.8 \\
\hline E. coli SMS-3-5 & 5068389 & 746734 & 589024 & 584759 & 517931 & 2438448 & 14.7 & 11.6 & 11.5 & 10.2 & 48.1 & 30.6 & 24.2 & 24.0 & 21.2 \\
\hline P. aeruginosa 01 & 6264404 & 376612 & 1171802 & 766117 & 707725 & 3022256 & 6.01 & 18.7 & 12.2 & 11.3 & 48.2 & 12.5 & 38.8 & 25.3 & 23.4 \\
\hline
\end{tabular}

*Genome constructed from 32 scaffolds (Accession: NZ_DS264553-DS264584).

MRSA = methicillin-resistant Staphylococcus aureus.

VRE $=$ vancomycin-resistant enterococci. 


\section{Implication for use as fecal indicator}

Sunlight irradiation, in particular UVB, played an important role in the endogenous inactivation of intact $B$. ovatus cells. To illustrate, the half-life of $B$. ovatus ranged from 9 to $13 \mathrm{~h}$ in low salinity and 16 to $34 \mathrm{~h}$ in high salinity solutions when sunlight irradiation was absent. This meant that if $B$. ovatus were to be released into either fresh or seawater environment in the evening or night-time, at least $50 \%$ of the cells would persist and remain detected by the next morning even though the contamination event may not be recent. On the contrary, if $B$. ovatus were to be released into fresh or seawater environment in the daytime, the cells would only persist for up to $6 \mathrm{~h}$, and a positive detection of $B$. ovatus would be indicative of the occurrence of fresh fecal contamination. Our observations, therefore, provide a possible explanation to account for the different test outcomes when monitoring the conventional fecal indicators at different times of the day $[39,40]$.

At the same fluence value exerted by the solar simulator, $B$. ovatus cells with intact membrane decayed much faster than the B. ovatus total DNA (Figure 3). The halflife of total DNA is from 40-100 times longer than that of the intact cells. This observation agrees with a previous study by Walters et al. [14], showing that a Bacteroidales human-specific DNA marker decayed slower than cells of the members in the Bacteroidales upon exposure to natural sunlight. This would imply that the currently proposed method by US-EPA to determine fecal pollution, which is based on the GPCR enumeration of the total DNA of the Bacteroidales, might still be limited in its efficacy to determine recent fecal contamination events.

A limitation of this study is that the high decay rates of $B$. ovatus may be attributed to the constant exposure to irradiance from the solar simulator, and may not represent the diurnal sunlight exposure in the natural environment. To illustrate, an earlier study did not observe a significant impact on the persistence of the species in the Bacteroidales in seawater under diurnal sunlight [4]. In the natural environment, temperature fluctuations, insufficient solar radiation transmittance, as well as possible absence of solar UVB due to the possible overcast weather may occur and prolong the persistence of the members in the Bacteroidales. Regardless, this study yielded similar $B$. ovatus decay trend at the early stage of the solar irradiation experiment $(<6 \mathrm{~h})$ as that obtained from a microcosm exposed to diurnal sunlight [17]. This suggests that the decay kinetic data obtained in this study remains useful in predicting the persistence of intact $B$. ovatus cell biomass after its release into the water environment. The decay kinetic data would allow subsequent calculation of the original amount of biomass upon release, and therefore assist in using this bacterial species as a general fecal indicator.

\section{Conclusions}

In this study, solar UVB was important for the persistence of intact $B$. ovatus in both low and high salinity water. $B$. ovatus had longer half-life in high salinity water than in low salinity water under the same conditions with full spectrum UV radiation $(0.21 \mathrm{~h}$ vs. $0.08 \mathrm{~h})$ and in the dark (34.12 h vs. $12.84 \mathrm{~h}$ ). In low salinity water, the half-life of $B$. ovatus under simulated full spectrum sunlight was enhanced by 4 -fold when $2 \mathrm{mg} \mathrm{C} / \mathrm{L} \mathrm{AOM}$ was present. Extracellular $\cdot \mathrm{OH}$ produced by $0.14 \mathrm{mM} \mathrm{NaNO}$ 2 did not have an observable effect on $B$. ovatus persistence. In high salinity water, neither $\mathrm{AOM}$ nor extracellular $\cdot \mathrm{OH}$ had significant effect on $B$. ovatus persistence. However, the synergistic effect of AOM and extracellular $\cdot \mathrm{OH}$ produced by $\mathrm{NaNO}_{2}$ led to the lowest $B$. ovatus half-life of $0.1 \mathrm{~h}$. Without exposure to sunlight, $B$. ovatus half-life ranged from $9 \mathrm{~h}$ to $34 \mathrm{~h}$ compared with $5 \mathrm{~min}$ to $13 \mathrm{~min}$ half-life of $B$. ovatus exposed to sunlight, depending on the solution that $B$. ovatus was present in. DNA degradation for $B$. ovatus under full spectrum sunlight irradiation was also observed, although the half-life of the total B. ovatus DNA is more than 100 -fold longer than that of the viable cells. The decay kinetic data reported in this study would help predict concentrations of $B$. ovatus cells or the DNA after their release into the water environment, therefore assisting in the use of this bacterium as a general fecal indicator. However, extrapolation to real environments has to be made carefully as a number of parameters, such as water depth, turbidity, biological interactions, were not considered in this study, and these parameters may also have an effect on the persistence of $B$. ovatus.

\section{Additional file}

Additional file 1: Table S1. Experimental design, research questions and findings. Figure S1. (a) Comparison of the persistence of B. ovatus irradiated by full spectrum simulated sunlight in low salinity water with and without AOM. (b) Comparison of the persistence of B. ovatus irradiated by full spectrum simulated sunlight in low salinity water and high salinity water with $0.14 \mathrm{mM} \mathrm{NaNO}$. (c) Comparison of the persistence of $B$. ovatus in artificial seawater irradiated by full spectrum simulated sunlight containing $\mathrm{AOM}$ and $0.14 \mathrm{mM} \mathrm{NaNO}$ ? with AOM. Error bars correspond to standard deviation of up to 5 replicates. Data were not corrected for light screening.

\section{Competing interests}

The authors declare that they have no competing interests.

\section{Authors' contributions}

PYH and THN conceived the study. SD performed the experiments, data analysis, and statistical analysis. SD, PYH, and THN participated in writing the manuscript. All authors read and approved the final manuscript.

\section{Acknowledgements}

This work was supported by NSF Career grant \#0954501. We would like to express our gratitude to Professor Roderick Mackie in the Department of Animal Sciences and the Functional Genomics Unit in the Biotechnology Center at the University of Illinois at Urbana-Champaign. We would also like to thank Hanting Wang for radical concentration data. 
Received: 1 January 2014 Accepted: 26 June 2014

Published: 4 July 2014

\section{References}

1. Cabelli VJ, Dufour AP, McCabe LJ, Levin MA: A marine recreational water quality criterion consistent with indicator concepts and risk analysis. J Water Pollut Control Fed 1983, 55(10):1306-1314.

2. Stevenson $\mathrm{AH}$ : Studies of bathing water quality and health. Am J Public Health Nations Health 1953, 43(5 Pt 1):529-538.

3. Menon P, Billen G, Servais P: Mortality rates of autochthonous and fecal bacteria in natural aquatic ecosystems. Water Res 2003, 37(17):4151-4158.

4. Bae S, Wuertz S: Discrimination of viable and dead fecal Bacteroidales bacteria by quantitative PCR with propidium monoazide. Appl Environ Microbiol 2009, 75(9):2940-2944.

5. Hou D, Rabinovici SJM, Boehm AB: Enterococci predictions from partial least squares regression models in conjunction with a single-sample standard improve the efficacy of beach management advisories. Environ Sci Technol 2006, 40(6):1737-1743.

6. Bae S, Wuertz S: Rapid decay of host-specific fecal Bacteroidales cells in seawater as measured by quantitative PCR with propidium monoazide. Water Res 2009, 43(19):4850-4859.

7. Fiksdal L, Maki JS, LaCroix SJ, Staley JT: Survival and detection of Bacteroides spp., prospective indicator bacteria. Appl Environ Microbiol 1985, 49(1):148-150.

8. Shanks OC, White K, Kelty CA, Hayes S, Sivaganesan M, Jenkins M, Varma M, Haugland RA: Performance assessment PCR-based assays targeting bacteroidales genetic markers of bovine fecal pollution. Appl Environ Microbiol 2010, 76(5):1359-1366.

9. Hong P-Y, WU J-H, LiU W-T: A high-throughput and quantitative hierarchical oligonucleotide primer extension (HOPE)-based approach to identify sources of faecal contamination in water bodies. Environ Microbiol 2009, 11(7):1672-1681.

10. Bernhard $A E$, Field $K G$ : Identification of nonpoint sources of fecal pollution in coastal waters by using host-specific $16 \mathrm{~S}$ ribosomal DNA genetic markers from fecal anaerobes. Appl Environ Microbiol 2000 66(4):1587-1594.

11. Whitman RL, Nevers MB, Korinek GC, Byappanahalli MN: Solar and temporal effects on Escherichia coli concentration at a lake Michigan swimming beach. Appl Environ Microbiol 2004, 70(7):4276-4285.

12. Ubomba-Jaswa E, Fernandez-Ibanez P, Navntoft C, Polo-Lopez MI, McGuigan $K G$ : Investigating the microbial inactivation efficiency of a $25 \mathrm{~L}$ batch solar disinfection (SODIS) reactor enhanced with a compound parabolic collector (CPC) for household use. J Chem Technol Biotechnol 2010, 85(8):1028-1037.

13. Sinton L, Hall C, Braithwaite R: Sunlight inactivation of Campylobacter jejuni and Salmonella enterica, compared with Escherichia coli, in seawater and river water. J Water Health 2007, 5(3):357-365.

14. Walters SP, Yamahara KM, Boehm AB: Persistence of nucleic acid markers of health-relevant organisms in seawater microcosms: implications for their use in assessing risk in recreational waters. Water Res 2009, 43(19):4929-4939.

15. Okabe S, Shimazu Y: Persistence of host-specific BacteroidesPrevotella 16S rRNA genetic markers in environmental waters: effects of temperature and salinity. Appl Microbiol Biotechnol 2007, 76(4):935-944

16. Bell A, Layton AC, McKay L, Williams D, Gentry R, Sayler GS: Factors influencing the persistence of fecal Bacteroides in stream water. $J$ Environ Qual 2009, 38(3):1224-1232.

17. Bae S, Wuertz S: Survival of host-associated Bacteroidales cells and their relationship with Enterococcus spp., Campylobacter jejuni, Salmonella enterica Serovar Typhimurium, and adenovirus in freshwater microcosms as measured by propidium monoazide-quantitative PCR. Appl Environ Microbiol 2012, 78(4):922-932

18. Davies-Colley RJ, Donnison AM, Speed DJ, Ross CM, Nagels JW: Inactivation of faecal indicator micro-organisms in waste stabilisation ponds: interactions of environmental factors with sunlight. Water Res 1999, 33(5):1220-1230.

19. Boehm AB, Yamahara KM, Love DC, Peterson BM, McNeill K, Nelson KL: Covariation and photoinactivation of traditional and novel indicator organisms and human viruses at a sewage-impacted marine beach. Environ Sci Technol 2009, 43(21):8046-8052.

20. Santos AL, Gomes NCM, Henriques I, Almeida A, Correia A, Cunha A: Contribution of reactive oxygen species to UV-Binduced damage in bacteria. J Photochem Photobiol B 2012, 117:40-46.

21. van der Meulen FW, Ibrahim K, Sterenborg HJ, Alphen LV, Maikoe A, Dankert J: Photodynamic destruction of Haemophilus parainfluenzae by endogenously produced porphyrins. J Photochem Photobiol B 1997, 40(3):204-208.

22. He $Y Y$, Hader DP: Involvement of reactive oxygen species in the UV-B damage to the cyanobacterium Anabaena sp. J Photochem Photobiol B 2002, 66(1):73-80.

23. Romero-Maraccini OC, Sadik NJ, Rosado-Lausell SL, Pugh CR, Niu X-Z, Croué J-P, Nguyen TH: Sunlight-induced inactivation of human Wa and porcine OSU rotaviruses in the presence of exogenous photosensitizers. Environ Sci Technol 2013, 47(19):11004-11012.

24. Silverman Al, Peterson BM, Boehm AB, McNeill K, Nelson KL: Sunlight inactivation of human viruses and bacteriophages in coastal waters containing natural photosensitizers. Environ Sci Technol 2013, 47(4):1870-1878.

25. Maraccini PA, Ferguson DM, Boehm AB: Diurnal variation in Enterococcus species composition in polluted ocean water and a potential role for the enterococcal carotenoid in protection against photoinactivation. Appl Environ Microbiol 2012, 78(2):305-310.

26. Horner RA: A Taxonomic Guide to Some Common Marine Phytoplankton. UK: Biopress; 2002

27. Robert C, Bernalier-Donadille A: The cellulolytic microflora of the human colon: evidence of microcrystalline cellulose-degrading bacteria in methane-excreting subjects. FEMS Microbiol Ecol 2003, 46(1):81-89.

28. Francis L, Ghaffour N, Alsaadi AS, Nunes SP, Amy GL: Performance evaluation of the DCMD desalination process under bench scale and large scale module operating conditions. J Membr Sci 2014, 455:103-112.

29. Romero OC, Straub AP, Kohn T, Nguyen TH: Role of temperature and suwannee river natural organic matter on inactivation kinetics of rotavirus and bacteriophage MS2 by solar irradiation. Environ Sci Technol 2011, 45(24):10385-10393.

30. Rojanasakul Y, Wang L, Hoffman AH, Shi X, Dalal NS, Banks DE, Ma JK: Mechanisms of hydroxyl free radical-induced cellular injury and calcium overloading in alveolar macrophages. Am J Respir Cell Mol Biol 1993, 8(4):377-383.

31. Carlsson J, Wrethen J, Beckman G: Superoxide dismutase in Bacteroides fragilis and related Bacteroides species. J Clin Microbiol 1977, 6(3):280-284.

32. Gregory EM, Moore WE, Holdeman LV: Superoxide dismutase in anaerobes: survey. Appl Environ Microbiol 1978, 35(5):988-991.

33. Eischeid $A C$, Linden KG: Molecular indications of protein damage in adenoviruses after UV disinfection. App/ Environ Microbiol 2011, 77(3):1145-1147.

34. Tuveson RW, Larson RA, Kagan J: Role of cloned carotenoid genes expressed in Escherichia coli in protecting against inactivation by near-UV light and specific phototoxic molecules. J Bacteriol 1988, 170(10):4675-4680.

35. McKinney CW, Pruden A: Ultraviolet disinfection of antibiotic resistant bacteria and their antibiotic resistance genes in water and wastewater. Environ Sci Technol 2012, 46(24):13393-13400.

36. Eddy FB, Williams E: Nitrite and freshwater fish. Chem Ecol 1987, 3(1):1-38

37. Garside C: A chemiluminescent technique for the determination of nanomolar concentrations of nitrate and nitrite in seawater. Mar Chem 1982, 11(2):159-167.

38. Rubio D, Nebot E, Casanueva JF, Pulgarin C: Comparative effect of simulated solar light, UV, UV/H202 and photo-Fenton treatment (UV Vis/H2O2/Fe-2+, Fe-3+) in the Escherichia colt inactivation in artificial seawater. Water Res 2013, 47(16):6367-6379.

39. Wyer MD, Kay D, Watkins J, Davies C, Kay C, Thomas R, Porter J, Stapleton CM, Moore $\mathrm{H}$ : Evaluating short-term changes in recreational water quality during a hydrograph event using a combination of microbial tracers, environmental microbiology, microbial source 
tracking and hydrological techniques: a case study in Southwest Wales, UK. Water Res 2010, 44(16):4783-4795.

40. Stapleton CM, Kay D, Wyer MD, Davies C, Watkins J, Kay C, McDonald AT, Porter J, Gawler A: Evaluating the operational utility of a Bacteroidales quantitative PCR-based MST approach in determining the source of faecal indicator organisms at a UK bathing water. Water Res 2009, 43(19):4888-4899.

doi:10.1186/1471-2180-14-178

Cite this article as: Dong et al.: Persistence of Bacteroides ovatus under simulated sunlight irradiation. BMC Microbiology 2014 14:178.

\section{Submit your next manuscript to BioMed Central and take full advantage of:}

- Convenient online submission

- Thorough peer review

- No space constraints or color figure charges

- Immediate publication on acceptance

- Inclusion in PubMed, CAS, Scopus and Google Scholar

- Research which is freely available for redistribution 